\title{
Ocorrência de Mollicutes no trato genital feminino de pequenos ruminantes no estado do Rio de Janeiro
}

Marcielli Silva Almeida, César Leandro David, Patrícia Mayumi de Oliveira Lima Abe, Aline Ethel Marques, Mário Felipe Alvarez Balaro1, Leandro dos Santos Machado, Virginia Léo de Almeida Pereira, Nathalie Costa da Cunha, Elmiro Rosendo do Nascimento

Faculdade de Veterinária, Universidade Federal Fluminense (UFF), Niterói, RJ, Brasil

*Autor correspondente

e-mail: elmiro@vm.uff.br

\section{Resumo}

Bactérias dos gêneros Mycoplasma e Ureaplasma estão relacionadas a desordens no trato reprodutivo em caprinos e ovinos. Juntamente com os testes sorológicos, avanços no diagnóstico pela reação em cadeia da polimerase (PCR) são usados a fim de melhorar e otimizar a detecção destes agentes. 0 presente estudo relata o diagnóstico e diferenciação molecular de ureaplasma em sete propriedades dos municípios de Nova Friburgo e Cachoeiras de Macacu, no estado do Rio de Janeiro, sendo duas com atividades relacionadas à caprinocultura (propriedades A e B) e cinco (propriedades C, D, E, F e G) à ovinocultura, dos anos 2013 a 2016. Foram coletados suabes vaginais de 203 fêmeas, sendo 175 ovelhas e 28 cabras. Os suabes foram submetidos à extração pelo método fenol-clorofórmio com posterior amplificação do DNA, com iniciadores específicos para a classe Mollicutes, gerando amplicons de 500 pares de base. Os produtos positivos da PCR foram purificados utilizando QIAquick PCR Purification Kit (Qiagen ${ }^{\circledR}$ ), quantificados no BioDrop Duo Main G.A ${ }^{\circledR}$, processados com o kit de sequenciamento Big Dye Terminator v3.1 (Applied Biosystems ${ }^{\circledR}$ ) e enviados a sequenciador Applied Biosystems ABI Prism 3730 ${ }^{\circledR}$. As sequências foram montadas e editadas com SeqMan, versão 7.0 do software DNAStar (Lasergene ${ }^{\circledR}$ ) e analisadas na base de dados do GenBank. Adotou-se o teste de Qui-quadrado, à 5\% de significância, para a comparação de frequências. Das amostras de suabes do trato reprodutivo coletadas, observou-se uma frequência de Mollicutes de 67,86\% (19/28) e 32,30\% (52/161) em caprinos e ovinos, respectivamente, com diferença significativa. Quanto às propriedades de criação caprina, a propriedade A apresentou uma frequência de 60\% (6/10) para Mollicutes, enquanto a propriedade $B$ apresentou 72,22\% (13/18). Em relação às propriedades de criação ovina, as propriedades C, D, E, F e G apresentaram frequência de 28,57\% (6/21), 17,50\% (14/80), 37,03\% (10/27), 43,75\% (7/16) e 88,23\% (15/17), respectivamente. Do total de amostras positivas até o momento, 19,72\% (14/71) destas foram sequenciadas e 50\% (7/14) foram positivas para Ureaplasma spp. Em conclusão, este relato reitera 
a importância do monitoramento e identificação de Mollicutes no trato genital de pequenos ruminantes. Igualmente, são necessários mais estudos para o esclarecimento do papel destes agentes na microbiota vaginal, assim como a sua possível associação a enfermidades no âmbito reprodutivo em caprinos e ovinos. 